\title{
Dušan Gabrovšek
}

University of Ljubljana

Faculty of Arts, English Department

\section{On Not Remembering/Knowing the Right Words: The Reverse Dictionary under Review}

\section{Summary}

The paper focuses on the onomasiological situation in monolingual dictionary consultation: When the reference need is not the typical one of looking up the meaning of an unfamiliar word or sense, but one of knowing what you want to say/write but cannot think of or do not know the right word(s). There are several English-language reference sources available that attempt to meet this kind of reference need, notably several "reverse" dictionaries, the Longman Lexicon, the Language Activator, the Superthesaurus, and a few more, including one online reference. Such sources are typically hybrid works, in the sense that they try to provide several kinds of lexical information that we normally expect to find selectively in different sources (general dictionaries, thesauruses, dictionaries of quotations, etc.). The work analyzed in some detail is the American Flip Dictionary (Kipfer 2000), designed "for when you know what you want to say but can't think of the word" (cover subtitle). User perspective in particular is highlighted.

Keywords: reverse dictionary, onomasiology, user perspective, concept

\section{Kadar nam prave besede umanjkajo: Analiza obratnega slovarja}

\section{Povzetek}

Prispevek se osredotoča na onomasiološko komponento pri rabi enojezičnega slovarja - ko ne potrebujemo pomena neznane besede ali pomena, ampak ko vemo, kaj želimo reči/napisati, a se prave besede ne moremo spomniti oz. je ne poznamo. V angleščini obstaja več del, ki skušajo zadostiti tej priročniški potrebi, zlasti “obratni” slovarji, Longman Lexicon, Language Activator, Superthesaurus ter še nekateri, med katerimi je vsaj eden vir elektronski. Ta dela so običajno hibridna, ker podajajo več vrst leksikalnih podatkov, katere običajno pričakujemo selektivno obravnavane v več vrstah jezikovnih priročnikov (splošni slovarji, tezavri, slovarji citatov itd.). Prispevek predstavi tudi ameriško delo Flip Dictionary (Kipfer 2000), ki je namenjen tistim, ki “vedo, kaj želijo povedati, a se ne morejo domisliti prave besede” (podnaslov na platnici). Še posebej je izpostavljena uporabniška perspektiva.

Ključne besede: obratni slovar, onomasiologija, uporabniška perspektiva, pójem 


\section{On Not Remembering/Knowing the Right Words: The Reverse Dictionary under Review}

\section{Introduction: A great variety of reference tools}

Most people will agree that dictionaries are indispensable. They provide a virtually unchallenged alphabetized inventory of words and phrases with information on their meanings; they may also teach us how to pronounce those words, and indeed how to use them, often supplying us also with etymology, selected encyclopedic material, and more. But there are, to be sure, other types of reference materials and their formats (McArthur 1995), demonstrating that dictionary users often need more than alphabetized inventories of lexical items invariably followed by the explanations of their meanings. Indeed, to take an example, it was over 25 years ago that Makkai $(1980,127)$ complained about dictionaries largely ignoring the associative groupings of lexemes as they form natural semantic nests around concretely observable and abstract (unobservable) entitites observing that their traditional reliance on alphabetization highlighted a totality of the available lexis while ignoring frequency of usage, exact range of dialectal habitat, the speaker's sociological status, etc. In short, it is clear that we may well be in need of a radically different, diversified type of dictionary than most of us are used to consulting, one incorporating not only an alphabetized list of words and their meanings or equivalents in another language but pictures and photographs, examples of use, encyclopedic and culture-related matter, usage notes, topicalized lists, miniature in-text lexical fields, and more, but it is evident that there can be no efficient single dictionary of this kind: Our lexical needs, expectations, reference skills, language proficiency, etc. are so vastly different!

\section{Onomasiology galore}

To get us going, let us briefly consider the need to have access to vocabulary items in a nonalphabetical manner (McArthur 1986). This can be implemented not only by dictionaries but also thesauruses, often referred to as word finders, today commonly alphabetical (Hanks 2000) rather than conceptual (Kipfer 2001), very occasionally both (Jelllis 2002), not infrequently seen as the only true "alternative" to dictionaries. Thesauruses have provided us, ever since Roget's 1852 pioneering Thesaurus of English Words and Phrases, first conceptually but later increasingly alphabetically too, with alternative ways of referring to - and talking about - a certain concept or idea and the items it is semantically closely related to, that is, its field, either in a synonym-oriented or lexical-field-oriented framework. Today, some of them are available online, such as Roget's Interactive Thesaurus (Kipfer 2004) which, by the way, probably supplies much more than you are ever likely to need, say as many as 40 entries when you type in the innocent-looking adjective entire. But is there anything in addition to thesauruses? Well, there is, in fact, more than one might think at first, though not really that much, at least when compared to the alphabetical semasiological (=word-to-meaning) reference tools known as dictionaries; for the English language, there are quite a few onomasiological (=meaning-to- 
word) reference sources, a category defined by "the direction from concept to word, rather than from word to explanation" (Hartmann and James 1998, 102). These include not only thesauruses and synonym dictionaries but e.g. McArthur's pioneering Longman Lexicon (1981), or the more recent Longman Language Activator (Summers 1993), plus its offshoot, The Essential Activator (Summers and Gadsby 1997), three hybrid works combining features of a dictionary and of a thesaurus. They basically build on a fairly old concept, one realized as early as 1902 in a Thesaurus Dictionary of the English Language created by the American philologist Francis A. March. However, the onomasiological dictionary today is a weak force compared to its A-Z cousin (Sierra 2000).

While for the purposes of this paper I will not discuss topical wordbooks such as The Word Menu (Glazier 1992) and Descriptionary (McCutcheon 1995), or topical reference works at large (e.g. Franck 1990), there is also the little used if heavily advertised "world's first full-language ideapinpointer," Henry Burger's controversial Wordtree (1984-), hailed as "the world's only fulllanguage Reverse Dictionary - it directs you from a mere idea to its precise wording," not to mention George Miller's WordNet, an electronic lexical tool available only on-line, basically a web of about 140,000 English words linked in a myriad ways, and the Plumb Design's Visual Thesaurus - launched in 1998 - that draws on the WordNet. ${ }^{1}$ But do such works cover all, or at least most, of the reference needs an average language user/learner is known to have? Not really. If conventional bilingual dictionaries do supply, for the most part, answers to our basic questions posed in the interlingual mode (what does this L2 [=foreign-languge] word mean? How do you say this L1 [mother-tongue] segment in an L2?), the monolinguals typically providing further support in terms of meaning - by definition - and usage, there is also a common vocabulary problem where you are aware of what you want to say but just cannot find or remember the word(s) to say it. Thus (Dobrovol'skij 1994, 263), while monolingual dictionaries are based on the principle "from sign to concept", and their bilingual counterparts on the principle "from sign to sign," what we still often miss are reliable dictionaries which are organized "from concept to sign" and can be used for text production.

\section{The reverse dictionary}

This is precisely where the reverse dictionary comes in, a fairly uncommon but general-audiencetype reference tool, the topic of this paper. ${ }^{2}$ Also known as the word-finding dictionary, this is "a type of reference work which supplies words for meanings" (Hartmann and James 1998, 156), and thus represents a distinct category of the onomasiological dictionary. It simply provides words you do not know or cannot think of but can "describe," and is a monolingualoriented largely native-speakers' encoding tool. In this paper, rather than focusing on the reverse

1 There exists, in addition to a desktop edition, an online edition of this interesting and original work, available at http://www.visualthesaurus. com/online/about.html. It basically shows the interrelationships between words and meanings as spatial maps.

2 Note that the term reverse dictionary is used in this paper in the "popular" word-finding sense; there is also the specialist scholarly variety also known as a tergo dictionary, reverse-order dictionary, or reverse index (Hartmann and James 1998: 119), a specialized tool for linguists listing words in alphabetical order according to their spelling from right to left, so that words ending in a come first, and those ending in $z$ come last, sofa e.g. coming among the first entries and fuzz among the last (Plag 2003: 75). This kind of organization is very convenient for the study of suffixes. 
dictionary of a single-feature, i.e. reverse-only, type (e.g. Bernstein 1988, Edmonds 2002), I will focus on a work (Kipfer 2000, another two such works being Sisson 1994 and Kahn 1989) that tries to combine the narrowly focused reverse dictionary with other features we have come to associate with dictionaries in general. This kind of work is typically monolingual, designed for encoding needs (finding the right words rather than understanding what they mean), and often advertised as a practical and useful vocabulary builder, word finder, memory jogger, and/or an entertaining and helpful work assisting one in doing crossword puzzles and helping other word game lovers (cf. e.g. Edmonds 2002, back cover). I am not aware of any such work being available on CD-ROM; only one - to the best of my knowledge - is currently available on the Internet ( OneLook); overall, it is very good, but shows the typical problems of so many online resources: It offers too much, and sometimes produces nonsensical results.

It is a fact that dictionary users know very little about how such a work is actually put together; even the editors of such works are as a rule tight-lipped as to how they went about making their work, at least judging from the front-matter sections. Likewise, there is very little to be found in the literature about how such works are really used. It certainly seems that the makers and users of such works as a rule do not engage in an awful lot of meaningful interaction. Moreover, there is no recognized basic entry format, or type of headword/headphrase, not even in theory, associated with the reverse dictionary: The entries can be single-word concepts, phrases, entire definitions, or some combination of these, not to mention additional features such as pictures, thesaurus entries, quotations, tables etc. Furthermore, it is likewise unclear what counts as a subentry and whether it should be there at all. The essential point is, in such a work there exists a non-general word you are groping for (target word), and the idea is to get you to that word via the simpler clue (or cue) words. The challenging idea - not addressed in this presentation, though - is whether such a work can be done in bilingual terms, and how exactly; if anything, it cannot be easy, because I am not aware of any such work for any given language pair.

Overall, the reverse dictionary does not seem to enjoy a place of pride among linguists and lexicographers, and it does not in all likelihood rank very high on the reference-tool list of most users either. The reasons for this state of affairs are not entirely clear, but certainly include the following:

(1) anything non-alphabetical and non-semasiological (=not going from word to the explanation of its meaning) is widely viewed with suspicion as being too subjective; only the alphabet is seen as a reliable and objective organizational principle.

(2) dictionaries are used in decoding (=interpreting meaning) much more than in encoding (=text generation), and they are traditionally associated with well-defined tasks of translating and interpreting word meaning. These facts militate against the reverse dictionary becoming a major mainstream reference tool.

(3) the best-recognized situation calling for a dictionary lookup is one where a "difficult" word or sense is encountered that needs to be checked. Not knowing a word for a concept 
is a decidedly "less serious" problem. This is doubtless why the reverse dictionary is often considered to have entertaining value only, as a curious work designed mostly for crossword puzzlers and word lovers. Moreover, the fact that there is no universal method of ordering associated with the reverse dictionary makes it somewhat inconspicuous on the rank list of respectable and useful reference sources.

\section{Digression: Concepts}

It is obvious that in this context, concepts are clearly important. Concepts are either universal ones, i.e. those that are shared by all human groups and in all probability are innate, or unique ones that belong to a single human group (usually, a single language community) and reflect this group's unique experience and way of life. Finally, intermediate concepts may be more or less widespread across cultures and reflect certain commonalities of human experience, or they may be characteristic of a certain geographic and/or cultural area, in which case they are likely to reflect commonalities of experience and way of life based on contact. According to a school of linguistic thought (Goddard 1996, 146), there are in every natural language only some sixty "apparently indefinable meanings," or semantic primes/primitives which we can expect to find expressed "lexically" in every language. They include substantives like I, yOu, sOMEONE, SOMETHING, PEOPLE, predicates such as KNOW, WANT, FEEL, SEE, HEAR, DO, HAPPEN, MOVE, SAY, determiner-like elements such as THIS, OTHER, THE SAME, ONE, TWO, MANY, ALL, spatial concepts like WHERE, HERE, UNDER, ABOVE, FAR, NEAR, SIDE, INSIDE, temporal concepts like WHEN, NOW, AFTER, BEFORE, logical elements like IF, BECAUSE, NOT, MAYBE, CAN, descriptive and evaluative concepts like BIG, SMALL, GOOD, BAD, and relational elements such as LIKE, KIND OF, PART OF. These can be expressed in a variety of ways, by affixes, (different) words, or fixed phrases. Could we possibly exploit these concepts in framing basic - vs. non-basic lexical onomasiological needs? In what way? By taking these to be truly basic, building from them onward? Not likely, as it does not seem to be the case that this could be a valid reversedictionary distinction from the users' viewpoint.

\section{Situations calling for the looking-for-words approach}

Let us, for starters, examine the following everyday situation, common to native-speakertype MONOLINGUAL exchange. You are talking (or writing, for that matter) about a president who had to leave office because he had done something real bad, and you start groping for the right word that just seems to elude you; it must be there, but whether it is on the tip of your tongue or nowhere at all, you would really like to find it and use it. You clearly need help, but what kind? Well, obviously something to lead you from the concept - whichever way you can express it - to the needed target word. ${ }^{3}$ In other words, you need lexical advice taking you from a general, "easy" word or concept/definition to a more specific, specialized, more "difficult" one. Note that there may be more than one "level" involved in what you need; you may, depending on the level of your linguistic sophistication, be, for instance, in need of

3 impeachment 
(a) a term for the link between sound and meaning in spoken language (sound symbolism), or

(b) the technical term for sound symbolism (phonesthesia).

While beyond the scope of this paper, the need for this approach in dealing with a foreign language shows in related INTERLINGUAL situations: This time you engage in translation work, and what happens is that

(a) you know a word in your mother tongue, say polovičar in Slovene, a rather negative term for a person who does things only superficially, in a generally unsatisfactory way, literally "only in half." You look up this word in an encoding bilingual dictionary (Slovene-English), but the word, sure enough, is not there;

(b) in translating a text into an L2, say English, you want to translate the Slovene word dioptrija or trebušnjak, only to you find, to your consternation and despair, that no SloveneEnglish dictionary lists it;

(c) you need to translate into English conventional Slovene word combinations such as prepričljiv poraz or proverb-like expressions such as brez muje se še čevelj ne obuje and dobre stvari so zmeraj tri. Needless to say, none can be found in that damn Slovene-English dictionary purporting to be one for encoding.

What are you to do? Clearly what is needed is an efficient source providing access to those items in English! But do we have sources that furnish us with this kind of badly needed lexical information, and, provided we do, are they really geared to our needs?

What certainly needs careful consideration is the issue of what kind of lexical items we need to retrieve in this non-alphabetical, concept-to-word fashion. The logical answer would be, in the monolingual mode at any rate, virtually everything but everyday, common-core items, that is, scientific and technical, dialectal, slangy, (somewhat) specialized, uncommon, obsolete, literary, etc. vocabulary. As there are thousands of such items in English, this obviously suggests a base problem - one of selection. Secondly but just as importantly, how are we to access those elusive "words hard to come by" - via (a) definitions, (b) merely simpler, broader concepts, (c) simpler synonyms whenever they exist, or indeed (d) some combination of these? And to top it all, should such a dictionary merge with a standard alphabetical dictionary "of definitions," i.e. a monolingual explanatory dictionary, however selectively?

\section{Reverse-style examples}

OK - let us consider matters the other way around: Look at the usefulness of the following fairly unconventional "lexical arrangement" taking you from simpler to more specialized lexical items:

TO BEGIN (of sth undesirable): to break out

BEGINNING: ( $\sim$ of sth unpleasant or difficult): onset

TO COLLECT, TO GATHER: - esp. information: formal to garner

COMPLETE [adj.]: (of sth undesirable): utter; unmitigated; rank; downright; arrant 
TO CRITICIZE: -severely: to pan

TO DECORATE: - food: to garnish

FAMOUS: - for something bad: notorious ; infamous

FULL OF (sth negative): rife with

TO INTRODUCE: - sth unpopular: to impose

TO PREVENT: $\sim$ sth bad: to foil

WIDESPREAD (of something bad): rampant

deadly food poisoning, as from canned food: botulism

device to measure the size of earthquakes: seismometer

getting better after taking a "dummy" drug: placebo effect

Stockholm's amusement park: Skansen.

\section{Open questions: Makers and users}

We certainly need to have vocabulary available in this way too, right? The problem is, how do we organize it? How "deep" is it to be? How extensive? One of such works (Edmonds 2002) claims 31,000 entries (=target words), but says nothing about the number of cue words; another (Kahn 1989) claims over 50,000 target words and more than 9,000 cue words. Is it enough? Which one? For what purposes? Moreover, can we identify a basic need: Finding the more abstruse synonyms of common words, or is it rather words for concepts that seem to be likely candidates for causing difficulty in remembering/knowing them? Indeed, are such works first and foremost "memory joggers" or "vocabulary builders" - or both? Could - should - a reverse dictionary be integrated with a full-blown conventional monolingual dictionary in a single alphabetical sequence, like some dictionary-cum-thesaurus-type of English-language reference works available from major publishers such as Oxford University Press and HarperCollins? These are serious questions, but the underlying message, I think, is that reverse dictionaries do not really fare well in the world of reference products. They are few in number, are exceedingly rarely reviewed in the literature, and are as a rule not studied from the viewpoint of either their compilers or potential users and their real needs. This just might be basically a reflection of the fact that dictionaries are chiefly known to be used primarily in decoding, not in encoding, meaning that what we do in consulting a dictionary is necessarily looking up the meaning of a certain lexical item; but then it might just as well be due to a tradition where alphabetization has reigned supreme for a long time, virtually unchallenged for several centuries...

\section{More than reverse dictionary information}

Anyway, the idea of offering a mere selection of vocabulary items "in reverse" seems to have struck some lexicographers as falling short of user expectations, so they responded with reverse dictionaries that offer more than that, for instance topicalized subject lists, tables, and/or pictures à la pictorial Duden dictionaries, plus conventional dictionary listings of defined items (Kahn 1989). This suggests that the mere reverse function is perceived to fall short of the needs of people likely to consult this sort of reference tool. 
One such work is the substantial American Flip Dictionary (Kipfer 2000); a 700-page affair, it sets out to help solve the lexical problem of "knowing what you want to say but not being able to think of the word", or of having "a general word in mind but you want something more specific" (back cover). Moreover, this (1) reverse dictionary is combined with (2) thesaurus entries while also offering numerous (3) tables covering subjects such as army, art, cocktails and mixed drinks, the human body, minerals, sports, some (3a) providing mere alphabetized lists, such as animal sports (p. 27) or apples (p. 32 ), others (3b) keeping the reverse-dictionary alphabetized-definition-first style, such as animal terms (p. 28) or basketball terms (p. 56). Certain thesaurus entries such as doctor, group, lens, are immediately followed by (4) "related terms" listings where the definition always begins with the headword it follows. It is in this way that this work promises to take you from a "meaning" you are aware of to the "word" you need (p. 1). These features are illustrated below:

(1) reverse dictionary

license to distribute company's goods or services in an area: franchise

light, allowing passage of: translucent, transparent

lighting technician on film: gaffer

limb falling asleep, tingling of: obdormition

(2) thesaurus entries

dictionary: glossary, lexicon, onomasticon, reference, vocabulary, wordbook, words encyclopedic: broad, complete, comprehensive, exhaustive, extensive, general, scholarly, thorough, universal

lip: border, brim, brink, edge, kiss, labellum, labium, margin, mouth, nozzle, rim, spout, tip; backtalk, insolence, sass

panic: alarm, anxiety, chaos, confusion, consternation, crash, dismay, dread, fear, frenzy, hysteria, overreact, scare, slump, stampede, terror, trepidation, unnerve

3) tables

(3a) bronco busting, bullfighting, bull riding, calf roping, camel racing ...

(3b) animal active at night: nocturnal animal active during the day: diurnal animal coat: fell, hair, hide, pelt, skin, wool body of dead animal: carcass

(4) "related terms" listings [following the entry lens] lens covering watch: lunette lens curved inward: concave lens curved outward: convex 


\section{Problems and suggestions}

If you consider the above examples, you are likely to be struck by several issues that still await definitive answers. Here are those I can think of:

- Who needs reverse dictionaries, how exactly do they use them, and in what communicative situations?

- "Multi-purpose" reverse dictionaries such as Kipfer (2000) are in essence hybrid works characterized by vague inclusion principles and unclear reference value; that is why it is their browsing and entertainment value that is most frequently singled out for special mention.

- The arrangement of such a work is always controversial, as there is no universal ordering schema. There seem to be no systematic or even prototypical reverse-dictionary needs.

- What kinds of lexical items do users of a reverse dictionary need to get access to?

- Should such a work combine the prototypical reverse-dictionary features with others such as pictures, defined items, topical lists, charts and tables, or not?

- Should the reverse dictionary be primarily a print dictionary or an online tool? Preferably the latter, but what about those users who do not have access to the Internet?

- Should it offer access to needed words via concepts or definitions? If the latter, how are they to be arranged and do you (and how) use cross-references?

As to suggestions for the $\mathrm{ABC}$ of making the reverse dictionary, here are those I believe are most worth mentioning:

(1) A reverse dictionary should preferably be reverse-type work only; definitions-based access seems to be the most useful one. However, it is true that additional features - particularly thesaurus entries - may make the work more attractive to potential buyers.

(2) It should be compiled on the basis of a clear methodology $y^{4}$ rather than as an idiosyncratic work echoing the mind of its compiler(s). Ideally, it should be based on (potential) user needs.

(3) There should not be an overwhelming number of items on the target side (users dislike not only not finding something but also having too much of it).

(4) It should be available in electronic (online) rather than book form, the reasons being the flexibility of format, the possibility of constant revision based on interaction with users, and the possibility for users to look for information via a range of potential routes. It would be ideal for users to simply input the concept to be searched through their ideas, using any words in any order.

4 On-the-spot comments on the topic of this paper, made immediately after the presentation, on 6 May 2004, included the interesting question of entry selection, and I suggested, as a possible first step, incorporating all labeled entries - or only those labeled for subject field - from a standard monolingual learner's dictionary (e.g. Summers ed. 2003 or Sinclair ed. 2003); later on, users would contribute substantially to expand the work in any possible way. Another question from the floor was whether a reverse dictionary of metaphors only is feasible; while the idea is challenging, such a work would be very difficult to implement, aside from the fact that this can be seen as a typical linguist's - in stark contrast to users' - suggestion. 


\section{Bibliography}

Bernstein, T.M. 1988. Bernstein's Reverse Dictionary. $2^{\text {nd }}$ edn., rev. and expanded by D. Grambs. New York: Times Books.

Dobrovol'skij, D. 1994. Idioms in a Semantic Network: Towards a New Dictionary-Type. In EURALEX 1994 Proceedings, ed. Martin, W., Meijs, W., Moerland, M., ten Pas, E., Sterkenburg, P. van, and Vossen, P., 263-70. Amsterdam: N.p.

Edmonds, D.J., comp. 2002. The Oxford Reverse Dictionary. Reissue, with corrections. Oxford Paperback Reference. Oxford: Oxford University Press.

Franck, I.M. 1990. On the Tip of Your Tongue: The Word/Name/Place Finder. New York: Signet.

Glazier, S. 1992. Random House Word MenuJ. New York: Random House. [new, expanded edn. 1997]

Goddard, C. 1996. Cross-Linguistic Research on Metaphor. Language \& Communication 16, no. 2 (April): 145-51.

Hanks, P.W., ed. 2000. The New Oxford Thesaurus of English. Oxford: Oxford University Press. [Rev. edn. 2004]

Hartmann, R.R.K. 1994. The Onomasiological Dictionary in English and German: A Contrastive Textological Perspective. In The World in a List of Words, ed. W. Hüllen, 137-49. Lexicographica, Series Maior \#58. Tübingen: Max Niemeyer.

Hartmann, R.R.K., and G. James. 1998. Dictionary of Lexicography. London: Routledge.

Hüllen, W. 1994. A Great Chain of Words: The Onomasiological Tradition in English Lexicography. In Anglistentag 1993 Eichstätt Proceedings, Volume XV, ed. G. Blaicher and B. Glaser, 32-46. Tübingen: Max Niemeyer.

Jellis, S., ed. 2002. Microsoft ${ }^{7}$ Encarta ${ }^{7}$ College Thesaurus. A Bloomsbury Reference Book. New York: St. Martin's Press.

Kahn, J.E., ed. 1989. Reader's Digest Reverse Dictionary. London: Reader's Digest Association.

Kipfer, B.A. 2000. Flip Dictionary. Cincinnati, OH: Writer's Digest Books.

Kipfer, B.A. 2004. Roget's Interactive Thesaurus. Available free at $h$ ttp://thesaurus.reference.com/help/faq/roget.html

Kipfer, B.A., ed. 2001. Roget's International Thesaurus ${ }^{7}$. $6^{\text {th }}$ edn. New York: HarperCollins Publishers.

Makkai, A. 1980. Theoretical and Practical Aspects of an Associative Lexicon for $20^{\text {th }}$ Century English. In Theory and Method in Lexicography: Western and Non-Western Perspectives, ed. L. Zgusta, 125-46. Columbia, SC: Hornbeam Press.

McArthur, T. 1986. Worlds of Reference. Cambridge: Cambridge University Press.

McArthur, T. 1995. Reference Materials and Their Formats. In The World in a List of Words, ed. W. Hüllen, 1-16. Lexicographica, Series Maior \#58. Tübingen: Max Niemeyer.

McCutcheon, M. 1995. Roget's Superthesaurus. Cincinnati, OH: Writer's Digest Books. [3 $3^{\text {rd }}$ edn. 2003]

OneLook Reverse Dictionary. http://www.onelook.com/reverse-dictionary.shtml.

Plag, I. 2003. Word-Formation in English. Cambridge Textbooks in Linguistics. Cambridge: Cambridge University Press.

Sierra, G. 2000. The Onomasiological Dictionary: A Gap in Lexicography. In EURALEX 2000 Proceedings, ed. U. Heid, S. Evert, E. Lehmann, and C. Rohrer, 223-35. Stuttgart: Universität Stuttgart/Institut für Maschinelle Sprachverarbeitung.

Sinclair, J. McH., ed. 2003. Collins COBUILD Advanced Learner's English Dictionary. $4^{\text {th }}$ edn. Glasgow: HarperCollins Publishers.

Sisson, A.F. 1994. Sisson's Word and Expression Locater. $2^{\text {nd }}$ edn. rev. by B.A. Kipfer. Englewood Cliffs, NJ: Prentice Hall. [First edn. published 1966]

Summers, D., ed. 1993. Longman Language ActivatorJ: The World's First Production Dictionary. Harlow, Essex: Longman Group UK. [rev. edn. 2002]

Summers, D., ed. 2003. Longman Dictionary of Contemporary English. New [4 $\left.{ }^{\text {th }}\right]$ edn. Harlow, Essex: Pearson Education/Longman.

Summers, D., and A. Gadsby, eds. 1997. Longman Essential Activator7: Put Your Ideas into Words. Harlow, Essex: Addison Wesley Longman.

Welcome to The Wordtree. http://www.wordtree.com/.

Willis, P. 1998. Review of Longman Essential Activator7, ed. D. Summers and A. Gadsby. International Journal of Lexicography 11, no. 4 (December): 357-65.

WordNet: A Lexical Database for the English Language. http://www.cogsci.princeton.edu/ wn/. 